Jana Coculova,

Ph.D., University of Presov, Slovakia

(D) ORCID ID 0000-0001-6105-3614

email: jana.coculova@unipo.sk

Nella Svetozarovova,

Ph.D., University of Presov, Slovakia

ORCID ID 0000-0003-4899-2013

email: nella.svetozarovova@unipo.sk

Daniela Bertova,

Ph.D., University of Presov, Slovakia

D ORCID ID 0000-0001-9559-3037

email: daniela.bertova@unipo.sk

Correspondence author: jana.coculova@unipo.sk

\title{
ANALYSIS OF FACTORS DETERMINING THE IMPLEMENTATION OF TALENT MANAGEMENT
}

Abstract. The paper deals with the issue of talent management, which is currently an integral part of effective human resource management. Talent management is now at the forefront because human resources, as bearers of knowledge and innovation, represent an irreplaceable business factor and a significant competitive advantage. The paper focuses on the implementation of talent management in terms of selected factors, which are assumed to be a key to the success of implementing talent management practices. Successful implementation of talent management is a prerequisite for achieving the set goals such as the acquisition, effective use and especially the retention of talented employees. The paper also presents the research results. The research aimed to determine whether there are statistically significant relationships between the selected factors and the successful implementation of talent management. The study was carried out on a sample of Slovak business entities, while the initial selection based on the question of whether the business entity has implemented talent management. Initially, out of 345 contacted Slovak business entities, only 58 of them commented positively on the implementation of talent management. The research sample consisted of talented employees of business entities that operate in the Slovak Republic and that have implemented talent management. Subsequently, the managers of these 58 organizations were approached to distribute the questionnaires to the «talented» employees. We received 83 questionnaires. The research subject is selected factors as possible determinants of talent management implementation: the existence of a talent pool; the existence of succession and career development plans; the degree to which the remuneration system is related to the performance of talented employees; support of education and development; support of innovation and creativity in talented employees. The success of the implementation of talent management as a dependent variable was assessed through 5 items using a 1 - 5 scale where a value of 1 represents strong disagreement and a value of 5 strong agreement. The consistency of these items was determined using Cronbach's alpha. For meeting the aim of the research, 5 statistical hypotheses were tested using the Mann Whitney $U$ test and the Kendall correlation coefficient. It was confirmed that succession planning, the flexibility of the remuneration system concerning the performance of talented employees, training and development support and creativity and innovation support in talented employees could be considered as determinants of successful implementation of talent management.

Keywords: human resource management, talent management, talent management implementation, talent pool, talented employee.

Introduction. Today, business entities are aware that acquiring the best talent is the key to success in today's global environment. Along with perceiving the importance of recruiting, developing and retaining talent, business entities have realized that talent is a critical resource that management needs to get the

Cite as: Coculova, J., Svetozarovova, N., \& Bertova, D. (2020). Analysis of Factors Determining the Implementation of Talent Management. Marketing and Management of Innovations, 3, 249-256. http://doi.org/10.21272/mmi.2020.3-18 
best results. In order to acquire and retain talented employees, it is essential to have implemented talent management, which includes several practices that support the effective use of talented human resources and at the same time lead to strong employee loyalty and commitment (lles, 2013). Talent management covers all aspects of the human resource development process and targets the growth and development of all employees (Thunnissen et al., 2013). The aim of talent management is not only attracting and recruiting the best people, but also defining and eliminating the wrong ones (Brockbank and Ulrich, 2009). On the other hand, talent management ensures that employees change positions within the business entity. Therefore the right people are chosen for the right job position at the right time (Kermally, 2004). Wall and Knights (2013) see talent development as an ever-evolving strategic resource that enables people to do their current and future tasks, helping them prepare for the changes that may come. Rothwell and Kazanas (2003) define talent development as a process of organizational change involving all interested parties using planned and unplanned training to achieve and maintain competitiveness now and in the future. In the paper, the focus is on the research of successful implementation of talent management, and the factors that determine this implementation. Knowledge of these factors is a prerequisite for achieving effective implementation of talent management in the organization.

Literature Review. The concept of human resource management in the 21 st century emphasizes the constant development of employees. Studies suggest that pressure on talent is growing (Jakubik, 2016). The goal of all organizations is to acquire high-quality, talented employees with the potential to grow in the labour market or among their existing employees. Mpofu and Hlatywayo (2015) and Pruis (2011) note that in an ever-changing business environment and given the highly competitive age, it is crucial for any business entity, small or large, local or international, to pursue activities to retain and develop talented employees. Haskins and Shaffer (2010) proposed a model for the implementation of talent management containing four components:

1) a thorough understanding of the aim of the business entity;

2) highlighting the attributes of talent development through the educational and development model;

3) strengthening lifelong learning during career development and management;

4) focus on the results achieved.

The main aims of talent management, in general, include retention of key employees, recognition of management positions at risk, description of the strategic program by indicating needs, abilities and human skills, defining and determining the existing situation in the organization in terms of skills, abilities and finding shortcomings and needs (Chugh \& Bhatnagar, 2006). There are also some secondary objectives of talent management, such as measuring and continuously monitoring existing competencies and their distance from optimal abilities and skills through strategies and training programs, recognizing, developing and maintaining the potential of employees, strengthening the position of stakeholders and understanding consumers, reducing external labour costs and challenges related to the management development (Saddozai et al., 2017). Talent management ensures that suitable people with the right skills are in the right job position. Their careers also act as a stimulating factor in improving the employment situation inside and outside the business entity. Talent management provides the right processes and tools to support and strengthen the position of managers. Business entities that want to invest in talent management can expect a high rate of return on their investment. It depends, in particular, on a sufficiently motivated workforce which contributes to the overall productivity (Sonnenberg et al., 2014). Also, selfesteem and motivation to improve are a direct result of implemented talent management strategies (Gallardo-Gallardo et al., 2013). For effective talent management, a quantitative and qualitative perspective of talent management is essential. It should be determined by the business goals and strategies of the business entities (Makela et al., 2010). Key concepts and elements of effective talent management include a clear understanding of the business entity's current and future business strategies. They define key gaps between the current and desired talent situation, and designing a reliable, 
comprehensive talent management plan to address key gaps (Tabatabaei and Mami, 2015). That program should be integrated into corporate strategies and personnel strategies to achieve the right type of personnel decisions (Ortlieb and Sieben, 2012). The way talent is managed and developed concerning the external environment or to existing corporate strategies should be considered an integral part of the effective internal organizational functioning (Meyers and Van Woerkom, 2014).

Hirsh (2009) defined 5 weak points in the implementation of an effective talent management strategy:

1. Talent management interventions should clearly target groups of jobs or people who, without active attention, may jeopardize the functioning of the business entity. Therefore, the key first question should not be «who is the talent?» but rather the «what is the place where the company needs to focus its talent management efforts»? It may be the case for talented employees at the beginning of the career, mid-career or close to the top (also specific job positions or various degrees of seniority, sometimes critical job positions) (Saadat and Eskandari, 2016). The business entity will often need to focus on several target areas in terms of talent management activities. Such an approach requires active development of the entire workforce, not its replacement.

2. Individuals need to be discussed in their careers and development. The conversation should be two-way and should focus on the future direction, not just the current situation. Talent and succession processes must be linked to the usual processes of individual performance management and development (Mellahi, 2010).

3. Managers need to work collectively in identifying and developing talent. Thus, they need clear rules for collective information sharing, decision-making and implementation. Discussions between managers should be linked from top to bottom across the business entity and simultaneously across divisional and geographical boundaries.

4. Individuals are developed through career and development activities. In turn, active career development is the basis for talent development (Barnett and Davis, 2008). Talent programs are often a version of skills training or coaching. Gaining access to the right range of work experience is key to gaining trusted successors at any level.

5. The human resources management department is to provide the necessary support for talent management, including information management and training (Mignonac and Richebe, 2013). Central teams should assist local business partners in identifying and developing potential at lower levels in the early stages of their careers.

Talent management brings along risks, too, for example, poorly defined competencies talented employees forming the talent pool should have. They were choosing future employees based on sympathies or behind-the-scenes policy and preference of selected employees for predetermined job positions. Poor selection of employees or wrongly set criteria thus leads to a non-return on investments put into talented employees (Rothwell and Kazanas, 2003). It is important that business entities implementing talent management also check the return on investment in this area of management, because if the company does not do so, talent management can become useless (Ghosh et al., 2013). The implementation of talent management programs requires good communication, proper setup and sufficient level of knowledge of all employees, not just the talented ones. Otherwise, these programs may lead to demotivation of those employees who are not involved in those programs or dissatisfaction of talented employees who are not allowed further growth in their careers (Milman and Dickson, 2014). It is necessary to take into account the individual differences and needs of selected talented employees. Still, on the other hand, the talent management programs themselves can lead to individualism and separation, which then lead to non-cooperation, thus negatively affecting the operation of the business entity.

Methodology and Research Methods. The research aimed to identify the determinants of successful implementation of talent management, by verifying the existence of a statistically significant relationship between selected factors and the success of the implementation of talent management (based on the 
perception of talented employees). The research was carried out on a sample of Slovak business entities, while the initial selection was based on the question of whether the business entity has implemented talent management. Initially, 345 Slovak business entities were contacted, but only 58 of them commented positively on the implementation of talent management. The research sample consisted of talented employees of business entities that operate in the Slovak Republic and that have implemented talent management. Subsequently, the managers of these 58 organizations were approached to distribute the questionnaires to the «talented» employees. We received 83 questionnaires. A two-part questionnaire provided collecting data. The first part of the questionnaire examined the presence of selected factors which represent independent variables. They are considered to determine the implementation of talent management in the business entity:

1. Created talent pool/a group of employees who are perceived by the business entity as talented.

2. Existence of career development plans and succession of talented employees.

3. The link between the remuneration and benefits system and the performance of talented employees.

4. Support for education and development based on the needs of talented employees.

5. Support for creativity, innovation, own proposals of talented employees.

The second part of the questionnaire contained items based on which the success of the implementation of talent management was determined. The success of the implementation of talent management as a dependent variable was assessed through 5 items using of $1-5$ scale. The value of 1 represents a strong disagreement and a value of 5 a strong agreement. The consistency of these items was determined using Cronbach's alpha. 5 statistical hypotheses were tested, Mann Whitney U-Test was used to test hypotheses $\mathrm{H} 1$ and $\mathrm{H} 2$, Kendall's correlation coefficient was used to test hypotheses $\mathrm{H} 3, \mathrm{H} 4$ and $\mathrm{H} 5$ (due to rank variables).

Results. The research aimed to determine whether there is a statistically significant relationship between selected factors and the perceived success of the implementation of talent management. The implementation of talent management was measured by 5 statements on which talented employees commented using a scale of $1-5$. The Cronbach's alpha coefficient aimed to verify the internal consistency of statements - it was found to be 0.910 , which shows a high degree of internal consistency of individual sub-items $(>0,7)$. The first factor that we assume determines the successful implementation of management talent is the existence of a talent pool in organizations. The talent pool represents a selected group of talented employees which the organization has clearly defined to implement specific practices to use their potential and to keep them in the organization.

$\mathrm{H} 1$ : We assume the existence of a statistically significant relationship between the existence of a talent pool and the successful implementation of talent management.

Table 1. The results of testing $\mathrm{H} 1$

\begin{tabular}{|c|c|c|c|c|c|c|}
\hline Existence of a talent pool & $\mathbf{n}$ & average & median & $\mathbf{U}$ & $\mathbf{z}$ & $\mathbf{p}$ \\
\hline Yes & 58 & 29.29 & 16.5000 & \multirow{2}{*}{4.376} & -1.668 & \multirow{2}{*}{.095} \\
\hline No & 25 & 37.43 & 18.0000 & & \\
\hline
\end{tabular}

Source: developed by the authors.

The Mann Whitney $\mathrm{U}$ test was used to test the hypothesis $\mathrm{H} 1$ - a $\mathrm{p}$-value $>0.05$, which means that the hypothesis must be rejected. The presence of a talent pool cannot be considered a determinant of the successful implementation of talent management. The second variable examined is the existence of the career development plan and succession plan for talented employees.

$\mathrm{H} 2$ : We assume the existence of a statistically significant relationship between the existence of the career development plan and succession plan and the successful implementation of talent management. 
The need for career development and career advancement is one of the most important needs of talented employees.

Table 2. Results of testing $\mathrm{H} 2$

\begin{tabular}{|c|c|c|c|c|c|c|}
\hline Existence of career development plans & $\mathbf{n}$ & average & median & $\mathbf{U}$ & $\mathbf{z}$ & $\mathbf{p}$ \\
\hline Yes & 60 & 22.93 & 15.0000 & \multirow{2}{*}{60.000} & -5.576 & $<0.001$ \\
\hline No & 23 & 50.14 & 22.0000 & & & \\
\hline
\end{tabular}

Source: developed by the authors.

Creating a career plan in cooperation with the needs of the employee is both a tool for retaining talented employees and also an important part of the business entity's personnel planning. Succession plans allow the business entity to plan out the use of the best employees for the future needs of the business entity, thus reducing the costs associated with recruiting staff from external sources, their subsequent training, etc. An important element for retaining talented employees is a properly set up system of remuneration and benefits. Therefore, for the remuneration system to be sufficiently motivating, it must be flexible, taking into account the real performance of employees. The degree of remuneration flexibility and benefits system concerning the performance of talented employees was examined as another factor influencing the implementation of talent management on a scale of 1 (low) to 5 (high).

$\mathrm{H} 3$ : We assume the existence of a statistically significant relationship between the flexibility of the remuneration and benefits system and the successful implementation of talent management.

Table 3. Results of testing $\mathrm{H} 3$

\begin{tabular}{|c|c|c|}
\hline The flexibility of the remuneration & tau & $\mathbf{p}$ \\
\cline { 2 - 3 } and benefits system & .420 & $<0.001$ \\
\hline
\end{tabular}

Source: developed by the authors.

Based on the obtained values, where $p<0.05$ and tau $=0.420$, it can be confirmed that there is a statistically significant relationship between the degree of flexibility of the remuneration and benefits system and the perceived success of the implementation of talent management. Based on the value of the correlation coefficient, we can speak of a moderately strong statistical dependence. A flexible system of remuneration and benefits can be considered a determinant of successful implementation of talent management. One of the features of a business entity that has implemented talent management is support for education and development. Talented employees have increased interest in their development, which requires continuous training. Therefore, it can be assumed that talent management will be implemented successfully only if the organization creates adequate conditions for acquiring new knowledge and skills of talented employees. Support for training and development was assessed on a scale of 1 (low) to 5 (high).

H4: Assumption of the existence of a statistically significant relationship between support for education and development and the successful implementation of talent management.

Table 4. Results of testing $\mathrm{H} 4$

\begin{tabular}{|c|c|c|}
\hline $\begin{array}{c}\text { Support for education and } \\
\text { development }\end{array}$ & tau & $\mathbf{p}$ \\
\cline { 2 - 3 } & .667 & $<0.001$ \\
\hline
\end{tabular}

Source: developed by the authors.

Using test statistics, we arrived at $p<0.05$, thus confirming the assumption that training and development are important factors in the successful implementation of talent management. The value of 
the correlation coefficient tau proves a strong correlation, and thus that it is an important determinant influencing successful implementation of talent management. Implementation of talent management can be considered more successful in the case of those business entities which significantly support the training and development of their talented employees. Another independent variable was the support of creativity, innovation, proposals of talented employees. For making the most of the potential of talented employees, the business entity must accept suggestions from talented employees. If the business entity accepts a talented employee, it proves his value, increases his self-confidence, thus supporting the loyalty and commitment of the employee. The given variable was measured on a scale of 1 (low) to 5 (high).

$\mathrm{H} 5$ : We assume the existence of a statistically significant relationship between the support of creativity, innovation and employee proposals and the successful implementation of talent management.

Table 5. Results of testing $\mathrm{H} 5$

\begin{tabular}{|c|c|c|}
\hline $\begin{array}{c}\text { Support for education and } \\
\text { development }\end{array}$ & tau & $\mathbf{p}$ \\
\cline { 2 - 3 } & .481 & $<0.001$ \\
\hline
\end{tabular}

Source: developed by the authors.

The H5 hypothesis was tested using the Kendall correlation coefficient. The $p$-value $<0.001$ allows the $\mathrm{H} 5$ hypothesis to be accepted, and the correlation coefficient value shows that the higher the business entity's support for creativity and innovation is, the more successful the talent management implementation could be. The relationship between the variables can be considered moderately strong. Based on the research results, it can be stated that hypotheses $\mathrm{H} 2, \mathrm{H} 3, \mathrm{H} 4$ and $\mathrm{H} 5$ were confirmed, hypothesis $\mathrm{H} 1$ was not confirmed. It was confirmed that most of the examined factors are determinants of successful implementation of talent management, namely the existence of career development plan and succession plan, a flexible remuneration system linked to performance appraisal, support for training and support for creativity, innovation. Based on the values of the correlation coefficient, support for education and development can be considered the most important determinant.

Conclusions. A prerequisite for achieving the benefits that result from employing talented employees is the successful implementation of talent management. The ability to attract a sufficient number of talented employees, to know how to make the most of their potential in terms of their future in the business entity and especially the ability to retain talented employees are signs of successful implementation of talent management. Therefore, for a business entity to achieve this, it needs to know and ensure several factors and procedures, which were also the subject of the research carried out on a sample of Slovak business entities. The research results confirmed that career development and succession planning, the flexibility of the remuneration system in relation to performance, support for training and support for creativity in talented employees determine the successful implementation of talent management.

Author Contributions: conceptualization, J. C.; data curation, J. C., N. S. and D. B.; formal analysis, J. C. and N. S.; funding acquisition, J. C. and D. B.; investigation, J. C., N. S. and D. B.; methodology, J. C. and N. S.; project administration, J. C. and D. B.; resources, J. C., N. S. and D. B.; software, N. S.; supervision, J. C. and N. S.; validation, J. C. and N. S.; visualization, N. S. and D. B.; writing - original draft, J. C., N. S. and D. B.

Funding: This paper is an outcome of the KEGA no. 012PU-4/2019.

\section{References}

Barnett, R., \& Davis, S. (2008). Creating greater success in succession planning. Advances in developing human resources, 10(5), 721-739. [Google Scholar] [CrossRef]

Brockbank, W., \& Ulrich, D. (2009). The HR business-partner model: Past learnings and future challenges. People \& Strategy, 32(2), 5-8. [Google Scholar]

Chugh, S., \& Bhatnagar, J. (2006). Talent management as high performance work practice: emerging strategic HRM 
dimension. Management and Labour Studies, 31(3), 228-253. [Google Scholar] [CrossRef]

Gallardo-Gallardo, E., Dries, N., \& Gonzalez-Cruz, T. F. (2013). What is the meaning of 'talent'in the world of work?. Human Resource Management Review, 23(4), 290-300. [Google Scholar] [CrossRef]

Haskins, M. E., \& Shaffer, G. R. (2010). A talent development framework: tackling the puzzle. Development and Learning in Organizations: An International Journal. [Google Scholar] [CrossRef]

lles, P. (2013). Commentary on "The meaning of 'talent'in the world of work". Human Resource Management Review, 23(4), 301-304. [Google Scholar] [CrossRef]

Jakubik, M. (2016). Talent engagement framework as a journey to performance. Review of Innovation and Competitiveness: A Journal of Economic and Social Research, 2(3), 101-122. [Google Scholar] [CrossRef]

Kermally, S. (2004). Developing and managing talent: a blueprint for business survival. Thorogood. [Google Scholar]

Makela, K., Bjorkman, I., \& Ehrnrooth, M. (2010). How do MNCs establish their talent pools? Influences on individuals' likelihood of being labeled as talent. Journal of World Business, 45(2), 134-142. [Google Scholar] [CrossRef]

Mellahi, K., \& Collings, D. G. (2010). The barriers to effective global talent management: The example of corporate elites in MNEs. Journal of World Business, 45(2), 143-149. [Google Scholar] [CrossRef]

Meyers, M. C., \& Van Woerkom, M. (2014). The influence of underlying philosophies on talent management: Theory, implications for practice, and research agenda. Journal of World Business, 49(2), 192-203. [Google Scholar] [CrossRef]

Mignonac, K., \& Richebé, N. (2013). 'No strings attached?': How attribution of disinterested support affects employee retention. Human Resource Management Journal, 23(1), 72-90. [Google Scholar] [CrossRef]

Milman, A., \& Dickson, D. (2014). Employment characteristics and retention predictors among hourly employees in large US theme parks and attractions. International Journal of Contemporary Hospitality Management. [Google Scholar] [CrossRef]

Mpofu, M., \& Hlatywayo, C. K. (2015). Training and development as a tool for improving basic service delivery; the case of a selected municipality. Journal of Economics, Finance and Administrative Science, 20(39), 133-136. [Google Scholar] [CrossRef]

Ortlieb, R., \& Sieben, B. (2012). How to safeguard critical resources of professional and managerial staff: Exploration of a taxonomy of resource retention strategies. The international journal of human resource management, 23(8), 1688-1704. [Google Scholar] [CrossRef]

Piyali Ghosh, P., Satyawadi, R., Joshi, J. P., \& Shadman, M. (2013). Who stays with you? Factors predicting employees' intention to stay. Organizational Analysis, 21(3), 288-312. [Google Scholar] [CrossRef]

Pruis, E. (2011). The five key principles for talent development. Industrial and commercial training. [Google Scholar] [CrossRef

Rothwell, W. J., \& Kazanas, H. C. (2003). The strategic development of talent. Human Resource Development. [Google Scholar]

Saadat, V., \& Eskandari, Z. (2016). Talent management: The great challenge of leading organizations. International Journal of Organizational Leadership, 5, 103-109. [Google Scholar]

Saddozai, S. K., Hui, P., Akram, U., Khan, M. S., \& Memon, S. (2017). Investigation of talent, talent management, its policies and its impact on working environment. Chinese Management Studies. [Google Scholar]

Sonnenberg, M., van Zijderveld, V., \& Brinks, M. (2014). The role of talent-perception incongruence in effective talent management. Journal of World Business, 49(2), 272-280. [Google Scholar] [CrossRef]

Tabatabaei, S. A. N., \& Mami, M. (2015). Investigating the Role of Talent Management System (TMS) in the Human Resources Management. International Journal of Human Resource Studies, 5(4), 36-49. [Google Scholar] [CrossRef]

Thunnissen, M., Boselie, P., \& Fruytier, B. (2013). A review of talent management:'infancy or adolescence?'. The international journal of human resource management, 24(9), 1744-1761. [Google Scholar] [CrossRef]

Wall, T., \& Knights, J. (Eds.). (2013). Leadership assessment for talent development. Kogan Page Publishers. [Google Scholar]

Яна Кокулова, Ph.D., Університет в Пряшеві, Словакія

Нелла Свєтозарова, Ph.D., Університет в Пряшеві, Словакія

Даніела Бетрова, Ph.D., Університет в Пряшеві, Словакія

Аналіз детермінант реалізації талант-менеджменту

у статті висвітлено особливості талант-менеджменту як невід'ємної складової ефекктивного управління людськими ресурсами. Зазначено, що рівень зацікавленоцсті світової наукової спільноти до вивчення проблематики талант-менеджменту з кожним роком зростає. Авторами наголошено, що людські ресурси є носіями знань та інновацій, представляють унікальний економічний ресурс та забезпечують отримання додаткових конкурентних переваг. Статтю присвячено аналізу ефеективності талант-менеджменту у в оргранізації. Авторами розглянуто, що основними цілями талант-менеджменту $є$ рекрутине, ефрективне управління талановитими працівниками та формування сприятливих умов для їх утримання в організації. Головною метою $\varepsilon$ визначення статистично значущих взаємозв'язків між досліджуваними детермінантами та ефективністю талант-менеджменту. у ході дослідження проведено опитування словацьких суб'єктів господарювання щодо ефекттивності застосовування талант-менеджменту. За результатами встановлено, що серед 345 опитаних суб'єктів господарювання, 58 мали досвід застосування талантменеджменту. Емпіричне дослідження проведено на основі панельних даних, сформованих для вибірки з 83 талановитих 
працівників відібраних суб'єктів господарювання. Предметом дослідження є запропоновані авторами детермінанти реалізації талант-менеджменту, а саме: наявність команди талановитих спеціалістів; плани щодо досягнення успіху та кар'єрного зростання; залежність розміру оплати праці талановитих працівників від результатів роботи; підтримка освіти та саморозвитку; підтримка інноваційності та творчості серед талановитих працівників. Оцінювання ефрективності талан-менеджменту, як залежної змінної, проведено за 5-бальною шкалою (1 - не погоджуюсь, 5 абсолютно погоджуюсь). Авторами застосовано коефіцієнт альфа Кронбаха для визначення узгодженості відповідей. Для досягнення мети дослідження перевірено 5 статистичних гіпотез за допомогою U-критерію Манна Уітні та коефіцієнта кореляції Кендала. Отримані результати підтверджують, що головними факторами ефективності талант-менеджменту є: планування досягнення успіху, гнучкість в оплаті праці талановитих працівників залежно від результативності; підтримка навчання, розвитку, творчості та інноваційності серед талановитих працівників.

Ключові слова: управління людськими ресурсами, талант-менеджмент, впровадження талант-менеджменту, команда талановитих спеціалістів, талановиті співробітники.

Manuscript received: 05.03.2020

(C) The author(s) 2020. This article is published with open access at Sumy State University 